\title{
Policy Issues and Consequences of Environmental Tax Reform Implementation in the Czech Republic ${ }^{\#}$
}

\author{
Petr $\check{S} A U E R^{*}-$ Ondřej VOJÁČ $E K^{* *}$ \\ Jaroslav KLUSÁK ${ }^{* * *}$ - Alena HADRABOVÁ ${ }^{* * * *}$
}

\section{Introduction: A Short Excursion into the History of Environmental Charging and Taxation in the Czech Republic}

Using economic instruments of environmental policy has had a long tradition in the Czech Republic. Pollution charges have been gradually introduced since the 1960s. Air emission charges were levied first in 1967. Charges for effluent wastewater into surface waters were instituted in 1979. Both internalization of external economic damage from environmental degradation and the trial-end-error procedure were considered as theoretical bases for the rates of the charges. However, in the centrally planned economy they played only a minor role in the decision-making process of the economic subjects.

\# This paper is one of the results of a research conducted within the project Resource productivity, environmental tax reform (ETR) and sustainable growth in Europe (PETRE), which is kindly funded by the Anglo-German Foundation (AGF). The methodology used was discussed within the project GACR no. 402/06/0806.

* Doc. Ing. Petr Šauer, CSc. - associate professor; Department of Environmental Economics, Faculty of Economics and Public Administration, University of Economics Prague, Winston Churchill sq. 4, 13067 Prague, Czech Republic, $<$ sauer@vse.cz>.

** Ing. Ondřej Vojáček - assistant professor; Department of Environmental Economics, Faculty of Economics and Public Administration, University of Economics Prague, Winston Churchill sq. 4, 13067 Prague, Czech Republic, <vojacko@vse.cz>.

*** Ing. Jaroslav Klusák - assistant professor; Department of Environmental Economics, Faculty of Economics and Public Administration, University of Economics Prague, Winston Churchill sq. 4, 13067 Prague, Czech Republic, <klusak@vse.cz>.

**** Doc. Ing. Alena Hadrabová, CSc. - associate professor; Department of Environmental Economics, Faculty of Economics and Public Administration, University of Economics Prague, Winston Churchill sq. 4, 13067 Prague, Czech Republic,<hadraba@vse.cz>. 
The current system of economic instruments of the environmental policy in the Czech Republic was introduced in the early 1990s during the process of establishing new state environmental policy and legislation.

The current system of environmental charges consists of air emission charges, sewage charges, water pollution charges, charges on municipal waste, charges on solid waste disposal, water extraction charges, charges for dispossession of agricultural and forest land, and mining charges.

Although charges have been perceived as working for environmental protection, they have been considered too narrow thanks to their focus on particular components of the environment. Also, as the environmental pollution has decreased, the revenue from the charges is relatively low compared to the administrative costs of their collection.

Environmental taxes started to be discussed in the first half of the 1990s within the process of transition to a market economy, when the changes to the entire tax system provided space for introducing new taxes. The act on public finance reform, which entered into force in 1993, provided a concrete scope for ET introduction - a specific paragraph was introduced to the tax act.

First discussions of environmental taxes started in the context of how to use environmental taxation in praxis for environmental protection. The initial idea was that ET and environmental charges could work in parallel, while the ET would focus on the environmental problems not covered by the charges (e.g. taxation of particular products such as paints).

The latter half of the 1990s was characterized by the intellectual shift from ET to ETR. The concept of the ET started to be perceived in a context of labour taxation lowering. This stage of the ETR preparation in the Czech Republic is connected with first calculation studies of potential ETR impacts. In those days, ETR became - with a certain degree of generalization - regarded as a really strong instrument in the environmental field especially among politicians and experts, namely those from the Ministry of the Environment. From the theoretical point of view, this period of the ETR debate was mostly based on the idea of the Pigouvian taxation and internalization of externalities, but the potential for revenue generation was also discussed. 
The concept on the environmental tax reform was first explicitly prepared by the Ministry of the Environment and the Ministry of Finance in the year 2000. The Czech Government discussed the proposal in the first half of 2001. Further work on the ETR was interrupted by Government Decree No. 652 of 25 June 2001.

The new governmental Coalition Agreement signed in June 2002 asserted the ETR as one of the goals and priorities of the new Government. The Government Agreement explicitly included a commitment to "start working on a revenue-neutral ETR in the Czech Republic". This intension was also traced in the "Proposal of a Public Finance Reform" (PFR) in 2002. After that, however, ETR was not included in the first phase of the PFR in 2003. Despite that, the PFR introduced a significant increase in excise duty rates on motor fuels (e.g., $0.42-0.49 \mathrm{Euro} / 1$ for petrol, $0.14 \mathrm{Euro} / 1$ for diesel oil, and $0.12 \mathrm{Euro} / 1$ for LPG) and simultaneously a decrease in income tax from $31 \%$ to $24 \%$ in 2006.

Another draft of the ETR was prepared in November 2003 and has been updated several times since then. For instance, there was a commitment to prepare a proposal of fiscal-neutral ecological tax changes in accordance with the EU laws in the program statement of the government in August 2004, and a working material of the Ministry of the Environment on ETR (MŽP 2005) was frequently discussed. Impact studies of the ETR implementation impacts have been developed as well (see, for instance, Ščasný et al. 2005, Beneš et al. 2006).

\section{Current state of the ETR introduction in the Czech Republic}

The exemption for the Czech Republic from EC Directive No. 203/96 will expire at the end of 2007. This was the main reason for the necessity to implement it at least at its minimal rates since January 1, 2008.

The final version of the ETR was approved by the Czech Government in May 2007. This version follows the above mentioned EC Directive, current Czech legislation, a Government Assignment, the official State Environmental Policy of the Czech Republic (MŽP, 2004), and the Official State Energy Policy of the Czech Republic (MPO, 2004). 
According to this version, from 2008 solid fossil fuels will be subject to a rate of 0.3 EUR per GJ of gross calorific value. This will trigger a rise in the price of solid fuels for households by approximately 10\%. Natural gas will be taxed at a rate of 1.1 EUR per MWh of gross calorific value. Electricity will be taxed by 1 EUR per MWh, which will cause approximately $1 \%$ increase in the household electricity prices. Electricity generated from renewable sources will be exempted from the taxation.

At the end, the Government opted to apply tax exemptions to:

- household heating with natural gas,

- district heating, if the heat is generated from combined heat and power technology,

- power and heat from renewable energy sources, methane and nitrogen fuel cells,

- the Government has retained the zero excise duty tax on the use of compressed natural gas in vehicles,

- electricity used in rail and traffic will not be subject to the excise duty either,

- coal used for production of electricity.

The Government approved a schedule of the future stages of the ETR implementation in the Czech Republic. According to this schedule, the ETR implementation is divided into three phases:

- Phase I consists of the implementation of Directive 2003/96/EC on taxation of energy products and electricity, and will be implemented from 2008;

- Phase II is focused on the transformation of air emission charges into environmental (carbon) taxes and the ETR fiscal neutrality fulfilment. This phase should be prepared by the end of 2008 and realized between 2010 and 2013;

- Phase III should be prepared by the end of 2012 and realized between 2014 and 2017. According to the governmental material, the ETR should be deepened and extended to other natural resources, natural services, etc.

New quantifications of the potential impacts of the ETR in the CR were conducted after the ETR was approved by the Government (see Ščasný - Brůha 2007, Zimmermannová 2007). 


\section{Literature review on ETR qualitative research}

A long process of preparations, full of changes and reversions, a period full of activity and inaction brought us to an interest in formulating research questions concerning the institutional background, to an effort to understand the true interests of interest subjects taking part in the "policy folklore dancing" process in the ETR preparation.

Qualitative research methodology seems to be more appropriate to this kind of research questions. Only few projects have been dedicated to qualitative research into the barriers of ETR implementation in Europe, and only one of them concerns the Czech Republic.

Most popular and known are the results of the PETRAS project (Policies for Ecological Tax Reform - Assessment of Social Responses). Dresner et al. (2006) summarised the most relevant barriers to ETR implementation, such as lack of trust about the use of the revenues, difficulty in understanding the purpose of a tax shift, and a desire for incentives for good behaviour as well as perceived 'penalties' for bad behaviour. Dresner et al. also made specific recommendations so that the acceptance of the ETR in CR increased, e.g. administration of the levies by an independent body, an explicitly shown reduction in direct taxes, or earmarking of ETR revenues for energy efficiency programmes or other environmental projects.

Pearce (2001) identified the following obstacles to the implementation of market-based instruments (MBIs): the legacy of legislative history, the threat that MBIs pose for regulatory capture (whereby those who are regulated spend resources influencing the regulator), inconsistent government goals and legislation, "picture thinking" about economics which is deeply engrained in the public's and media's minds, media obsession with losers not winners, and politicians' unwillingness to present the environmental case in a context where, whatever the rhetoric, the environment is simply not a dominant political priority.

Dunne et Clinch (2004) undertook research focused on attitudes of the business sector to ETR in Ireland. The awareness of the ETR was generally found to be very low, with just some vague knowledge of the recent British changes in this regard. The general awareness level regarding environmental issues was quite high, but mostly in relation to the day-to-day environmental issues of the given company, including 
mostly Environmental Protection Agency requirements and Integrated Pollution Control licences.

The type of business seemed to have some effect on the knowledge of ETR and environmental taxes generally, with the bigger companies who would be adversely affected keeping a closer eye on what was likely to happen in this regard. Even companies that would seem to be more labour intensive stated that they would need to look more closely at the figures before they could decide if they would benefit or suffer from such initiatives. The younger company representatives seemed to be more accepting of the ETR ideas presented in the interview. The impact of ETR on competitiveness was of some concern to the interviewees. In Ireland and the UK, there was a concern that environmental tax reform could lead to job losses rather than gains.

EEA (1996) defined important political barriers to the introduction of environmental, particularly energy taxes as follows: the perceived impacts on competitiveness, and often on employment, particularly in some sectors/regions, the perceived impacts on low-income groups (i.e. the poor may pay proportionally more than the rich), perceived conflicts between national taxes and EU, or world trade, rules, the EU unanimity rule when voting on fiscal measures, perceptions that the taxes have to be high if they are to work, the perceived conflict between changing behaviour (i.e. less tax) and maintaining revenues, existing subsidies and regulations etc. that provide environmentally perverse effects; and other policies and cultures which negate or inhibit environmental taxes.

\section{Qualitative research within the PETRe project}

\subsection{Methodology}

The methodology of qualitative research was used for the analysis of practical barriers and obstacles to ETR implementation in the CR. The knowledge of the theoretical background of ETR, findings from the quantitative studies concerning the potential impacts on particular stakeholders, and knowledge gathered from frequent working contacts with people representing various stakeholders were taken into consideration at the beginning of the preparation of the research. 
The following research questions were set before the qualitative research started:

- Who are the main stakeholders involved in and influenced by the ETR in the Czech Republic?

- Are environmental taxes, and/or ETR viewed as a suitable instrument for energy efficiency improvement?

- Do various groups of stakeholders have different attitudes to environmental taxes and ETR? What are the main differences?

First, problem focused interviews were realized with two main key experts who have been participating in the ET and ETR discussions and preparation in the Czech Republic since the very beginning. The first one was from a research institute, the other one from the Ministry of the Environment, previously working at the Ministry of Finance department responsible for financing environmental protection from the state budget. A questionnaire was prepared for the focused interviews.

Based on the results of the focused interviews, questionnaires for semi-structured interviews were developed. Representatives of public administration bodies, the industry sector and labour unions were the first subjects included in this stage of the research.

The questionnaires contained the following areas developed into sets of open-ended questions:

- awareness and detailed knowledge of ETR;

- identification of main stakeholders' interests;

- comparison of acceptance of ETR and other environmental policy instruments for particular subjects;

- knowledge of the ETR impacts on the interviewed subject;

- main costs and benefits to particular subjects;

- Perceived positives and negatives of the ETR implementation for the subject;

- ETR influence on the process of innovation and energy saving provisions in the companies;

- What factors could change the subject's attitude to the ETR if it is negative.

A total of 7 interviews was realized: 3 interviews with public administration bodies, 2 interviews with industry sector 
representatives, 1 interview with a labour union representative and 1 interview with an NGO representative.

\subsection{Preliminary results of the research}

The preliminary results of the qualitative research follow the main research areas formed above.

\section{Awareness and detailed knowledge of ETR}

Different attitudes to the ETR concept occur among interviewed stakeholders. The Ministry of the Environment $(\mathrm{MoE})$ representative considered ETR to be an appropriate instrument to move the Czech Republic towards low carbon and a competitive economy. The Ministry of Finance (MoF) perceived ETR as a fiscal instrument helping to decrease the state budget deficit, but stated that the current ET rates do not generate significant revenue. Nearly all the industry representatives focused only on the "taxed" part of the ETR.

The interviewed stakeholders had no common understanding of the main goal of the ETR in the Czech Republic. The understanding of the ETR goals was very different among the subjects. It varied from taxation of externalities to improvement of energy efficiency, public health improvement, additional revenue generation, and having a more energyefficient economy.

Some of the representatives also confirmed the exaggerated expectations from the ETR. The ETR concept became most popular in the latter half of the 1990s and was very often viewed as a powerful and almighty environmental policy instrument; e.g. ETR was mentioned in the proposals for the Waste Management Plan of the Czech Republic. NGO representatives also confirmed it by assessing environmental taxes as a potential source of money for environmental protection.

Awareness of ETR principles was sufficient among the interviewed representatives, but attitudes to the practical realization of the fiscal neutrality of the ETR varied among them. Representatives of Labour unions were sceptic to the fiscal neutrality principle, because they were aware of the need for a social insurance increase. Representatives of public administration worried about the transaction (indirect) costs of the ETR implementation (especially the Ministry of Finance). Phase I of the 
ETR (implementation of Directive 2003/96/EC on taxation of energy products and electricity) will be accompanied by higher administrative burden (about 300 extra jobs needed), these personal costs represent about $5 \%$ of the environmental tax revenues in the year 2008 .

ETR was not supported by any significant PR campaigns explaining the positive impacts of the ETR process (lower labour cost, decreasing energy dependency, etc.). Also, only few stakeholders (except public administration) were invited to cooperate in the process of public hearings.

All interviewed subjects were quite well informed about the ETR concept, including the impacts of its various alternatives. However, they stressed the opinion that the general public is not informed about the ETR.

\section{Revealed interests of the main stakeholders of ETR}

Industry representatives and labour union representatives worried about energy prices and argued for minimizing the tax rate increase in the next phases of ETR; on the other hand, the industry representatives confirmed that they had expected higher tax rates than those included in ETR Phase I. They would agree with increasing tax rates in case they could transfer the energy price increase into output price. Industry representatives also stressed the anxiety whether the energy efficiency measures would be possible to realize if their profits were lowered by the energy taxation.

Representatives of labour unions were afraid of parallel effects of the new energy taxation due to Directive 2003/96/EC and the VAT rate increase for heat produced in central heating plants, which will both enter into force on 1 January 2008 and will increase households' living cost.

The Ministry of the Environment would like to speed up the implementation of a fiscal-neutral ETR, with recycling in social insurance fees, because they view ETR as a really powerful instrument. The Ministry of Finance had doubts about environmental taxes and ETR due to their uncertain revenue and decreasing rates of the revenue over time if the environmental situation improves. The NGO representative supported the idea and process of ETR implementation due to its double-dividend theory. 


\section{Comparison of acceptance of ETR and other environmental policy instruments}

The idea that "ETR is implemented just for ETR itself" was mentioned by some of the public administration representatives. The underlining idea of ETR as a tool of both environmental and economic policy was lost during the implementation process. According to one of the key administration representatives, at the end of the preparation process the only aim was to fulfil the minimum requirements of $\mathrm{EU}$ Directive 2003/96/EC and minimize the risk of interest barriers of the key stakeholders, namely the Ministries.

Some of the public administration representatives also worried about the transformation of the existing system of environmental charges to environmental taxes in the next intended phases of the ETR implementation. Environmental charges still generate important revenues for the State Environmental Fund, which co-finances Structural Fund projects till 2013 focused on improving the quality of the environment.

Czech political bodies were also criticized for no effort to utilize the maximum transitional period of Directive 2003/96/EC on taxation of energy products and electricity implementation, which it was possible to postpone till the year 2012. They also agreed that Phase I of ETR would have no significant impacts on the industry sector.

Finally, the industry and labour union representatives agreed that ETR would have no important potential impacts on energy savings, that ETR can motivate only low-budget energy saving measures but not expensive investments. It was emphasised that the average expected electricity price increase for final consumers of $1 \%$ can differ from the company electricity price increase when electricity is produced by the company itself (counted as a ratio to the internal price for company power supply prices -2.2$)$

As expressed by the industry representatives, the price increase thanks to ETR has to be seen in the context of price increases for other reasons. It was also strongly emphasised that the price increase has to be seen in the context of the respective sector's competitiveness.

The potential lack of allowances in the third period of the EU Emission trading scheme (ETS) was mentioned in several cases 
(especially by the energy production sector) as a strong instrument to change future relative prices significantly.

The ETR concept would be most plausible among the interviewed stakeholders if more was known about the ETR revenue recycling process. Industry representatives also preferred that the revenues from the ET were used for financing environmental protection projects.

\subsection{Discussion}

There is a great deal of controversy about the economic consequences of ETR. Proponents of the "double dividend" hypothesis on the one hand argue that the cuts in direct income taxation overweigh the burdens of the increase in indirect taxation, so that the ETR will not only improve the environment, but also increase employment and economic growth. On the other hand, if the cut in the direct taxes is not effective enough (for instance due to enormous administrative costs), then the ETR may have very adverse effects on the economy, including negative impacts on the industrial competitiveness and welfare. If the tax base of the environmental taxes is going to erode, the ETR can cause problems of unstable public finance.

The transaction costs of the "fiscal neutrality" measures are not known yet; there are still a few estimations for Phase I of ETR (with no fiscal neutrality requirements) available, as mentioned above. Effects of the cut in the direct taxation have still not been precisely estimated and as known from Germany and UK experience, it is really hard to value effects of the direct tax cut on the economic productivity. The Czech Republic and other CEE countries have (due to their energy intensive economies) truly big potentials for energy savings.

There is one really important question, which is also supported by the preliminary results of our qualitative research in the Czech Republic. It is the question whether to transfer the ET into charges, or whether the charges are to be cancelled and all payments connected with the environment should be realized through ET.

Both alternatives have their pros and cons and are nowadays subject to discussion among the politicians and environmental experts. As already mentioned, one of the concerns connected with the abolition of charges is the loss of revenues for the State Environmental Fund, while others argue 
that this fund is not easily publicly controlled and also the administrative costs of the revenue collection are unreasonably high. Bearing in mind that charges have no stimulating function on the companies in the CR, because they are much lower than the marginal abatement costs are, it is hard to find any argument why to keep the charges under the given circumstances.

On the other hand, several arguments can be found for preserving the charges. As mentioned above, their long-standing tradition is one of them. The other is the question of administration of the revenues in the CR. While the ET flow to the state budget, the charges flow mainly to the State Environmental Fund, which can then co-finance environmental protection programmes.

Objectively, if the main goal of the environmental charges is just to get revenue rather then motivate polluters to reduce their emissions, then the revenues could be gained in cheaper ways than by charges, such as by increasing VAT etc., where the administrative costs are much lower and the marginal administrative costs would be close to zero.

\section{Conclusion}

The first stage of the research in the Czech Republic showed several important preliminary results, which should be taken into account in the process of ET and ETR implementation in the Czech Republic and maybe also in other CEE countries. They are as follows:

It seems that during the process of the ETR preparation, the reason for implementation as well as the intended goal of ETR implementation was more or less lost.

The main goal of the ETR was not formulated and especially publicly promoted so far in the Czech Republic, which can partly explain why the interviewed stakeholders' opinions on the ETR importance varied. The goal of the ETR thus could not and in reality was not broadly claimed; public relations in the case of ETR or environmental taxes were insufficient and downgraded.

On the one hand, the first period of Directive 2003/96/EC on taxation of energy products and electricity implementation was not at the most utilized for energy efficiency stimulation. On the other hand, the question 
arises whether new EU Members should have the same goals concerning environmental quality as the old members, and what should be the degree of their independency in formulating their environmental policy goals. But it might work as a long-term strategy of environmental policy. There is a question whether it would be possible to change the institutional settings around the State Environmental Fund, so that it can play a better role both in environmental protection and effective management of the financial resources from EU Structural Funds designed for environmental protection.

On the one hand, the environmental charges do not fulfil their environmental protection motivation function, since their rate is mostly much lower than marginal control costs or, in many cases, the target has already been achieved; and it is practically impossible to have their increase passed in the Parliament. Also, current administrative costs of collecting the revenue are too high compared to other options of getting money for public funds. On the other hand, this form of economic environmental protection stimulation has had a long-standing tradition. The charges are well understood as a form of effort to stimulate better environmental performance of polluters. Future research should also show what is the right decision for environmental policy and stimulation strategies in the long run.

\section{References}

[1] Beneš, M. et al. - Fialová, H. - Starý, O. - Urbanová, T. - Vastl, J. Vašíček, J. (2006): Analýza koncepce ekologické daňové reformy. [on-line]. Praha, Faculty of Economics and Public Administration, University of Economics, Prague / Faculty of Electrical Engineering, Czech Technical University in Prague, c2006, [cited 13 ${ }^{\text {th }}$ April, 2008], <http://fnh.vse.cz/download/studie/edr_studie.pdf $>$.

[2] Dresner, S. - Dunne, L. - Jackson, T. (eds.) (2006): Special issue: Social and political responses to ecological tax reform in Europe. Energy Policy, 2006, vol. 34, no. 8.

[3] Dunne, L. - Clinch, J. P. (2004): The Perception and Attitude of Business to the Environment and Environmental Tax Reform: Some observations from an Irish Case Study. Planning and Environmental Policy Research Series (PEP), Working Paper 04/02. Dublin, 
University College, Department of Planning and Environmental Policy, 2004.

[4] EEA (1996): Environmental Taxes - Implementation and Environmental Effectiveness. Copenhagen, European Environmental Agency, 1996.

[5] Pearce, D. W. (2001): What Have We Learned from the UK's Experience with Market-Based Instruments? In: McCoy, D. - Scott, S. (eds.): Green and Bear It? Implementing Market-Based Policies for Ireland's Environment. Proceedings of a Conference. Dublin, ESRI, May 10, 2001.

[6] MPO (2004): State Energy Policy of the Czech Republic. Praha, Ministry of Industry and Trade of the Czech Republic, 2004.

[7] MŽP (2004): State Environmental policy of the Czech Republic 2004-2010. Praha, Ministry of the Environment of the Czech Republic, 2004.

[8] MŽP (2005): Conception of Environmental Tax Reform. (in Czech: Koncepce ekologické daňové reformy, pracovní materiál MŽP ČR.) Praha, Ministry of the Environment of the Czech Republic, 2005.

[9] Ščasný, M. et al. (2005): External costs of electricity and heat production in the Czech Republic and methods of their internalisation. (in Czech: Externí náklady výroby elektřiny a tepla $v$ podmínkách $\check{C} R$ a metody jejich internalizace). Final project report MŽP VaV c. 320/1/03. Praha, Charles University, 2005.

[10] Ščasný, M. - Brůha, J. (2007): Prediction of Social and Economic Impacts which Implies from Proposal of First Phase Environmental Tax Reform in the Czech Republic. (in Czech: Predikce sociálnich a ekonomických dopadi návrhu první fáze ekologické daňové reformy České republiky.) Praha, Charles University, 2007.

[11] Zimmermannová, J. (2007): Impact of the electricity, natural gas and solid fuels taxation on the companies in the $\check{C} R$. Working papers of Environmental Economics. Praha, University of Economics, Prague, 2007. 


\title{
Policy Issues and Consequences of Environmental Tax Reform Implementation in the Czech Republic
}

\author{
Petr $\check{S} A U E R$ - Ondřej VOJÁČEK - Jaroslav KLUSÁK - \\ Alena HADRABOVÁ
}

\begin{abstract}
Optimal policy design should maximize environmental benefits and minimize negative impacts of the environmental tax reform (ETR) on economy and society. Both researchers and policy makers are interested in potential impacts of ETR implementation as perceived by the relevant stakeholders. Qualitative research methodology was used for answering the key research questions.

The aim of this paper is (1) to bring a brief information on the history of introducing environmental charges and taxes in the Czech Republic, (2) to bring an overview of the main results of qualitative research focused on ETR perceptions conducted abroad, (3) to discover practical barriers and obstacles in the process of ETR implementation in the Czech Republic perceived by key stakeholders and (4) to make an attempt on formulation of recommendations for the ETR implementation process in the Czech Republic.
\end{abstract}

Key words: Environmental charges; Environmental tax reform; Stakeholders; Environmental policy tools; Czech Republic; Qualitative research.

JEL classification: $\mathrm{H} 23$. 